\title{
Tratamiento de las Neoplasias intraepiteliales de la vagina con 5-Fluorouracil tópico
}

\author{
Dres.: Raúl Llanos, Phillip J. Krupp, James W. Bohm y David E. Barnard \\ SECCION DE ONCOLOGIA GINECOLOGICA \\ DEPARTAMENTO DE OBSTETRICIA Y GINECOLOGIA \\ Tulane Medical Center - New Orleans, Louisiana
}

La historia natural de la neoplasia intraepitelial en la vagina es pobremente interpretada. Los factores y el tiempo requerido para que una displasia progrese a carcinoma invasivo no son conocidos. La asociación frecuente de carcinoma de la vagina con cáncer de la vulva y del cervix sugieren un factor carcinogénico común. La displasia intraepitelial vaginal a menudo es multicéntrica.

Diferentes formas de tratamiento en la neoplasia intraepitelial de la vagina, tales como extirpación quirúrgica, fulguración, irradiación y crioterapia, aunque efectivos, pueden resultar en perdida de la función vaginal.

El uso tópico de 5-FU también ha sido reportado con éxito en el tratamiento de neoplasia vaginal intraepitelial. Tratamiento simultáneo de múltiples focos con displasia cicatrizando con muy poca fibrosis, con preservación del ta- maño y función de la vagina son predecibles cuando esta forma de tratamiento es exitosa. La evidencia acumulada parece apoyar más irivestigaciones en este sentido particularmente con referencia a la selección de pacientes y la forma de administración.

Seis pacientes con neoplasia vaginal intraepitelial recibieron tratamiento con 5\% Flurouracil; suatro pacientes con Carcinoma In Situ y dos pacientes con Displasia. Todas las pacientes respondieron en forma favorable al tratamiento. Esta serie de pacientes representan una experiencia adicional en la terapia de neoplasias intraepiteliales, utilizando la aplicación tópica de 5-FU de acuerdo con un régimen relativamente estandar. Las apreciaciones colposcópicas de la vagina durante las diferentes fases del tratamiento son mostradas y el resul tado final que evidencia la eficacia de esta forma de tratamiento también. 


\section{MATERIALES Y METODOS}

Seis pacientes con citología anormal fueron diagnósticadas $y$ tratadas en un período de dos años en el servicio de Oncología Ginecológica en el Tulane Medical Center de New Orleans, Louisiana.

Estas seis pacientes que son presentadas en este estudio tienen un historial clínico diferente, pero tienen en común cambios neoplásicos en los diferentes cortes histológicos. Ellas representan dos años de experiencia con una forma estandar de tratamiento, además de su seguimiento clínico.

Después de haber terminado con su evaluación y diagnóstico, las pacientes fueron instruidas acerca de la aplicación de crema 5\% 5-FU y el uso del diafragma por cinco días consecutivos en la semana durante las seis semanas siguientes. Vaselina $u$ otro ungüento que actuara como barrera para proteger a la piel de la vulva les fue recomendado. Quejas asociadas con el tratamiento se trataron sintomáticamente. Biopsias durante los exámenes colposcópicos en las diferentes fases del tratamiento se tomaron. Cuatro de las pacientes revelaron carcinoma in situ y las dos restantes mostraron displasia.

\section{RESULTADOS}

La tabla número 1 y 2 es un resumen de nuestras experiencias usando el proto-colo ya mencionado.

Como se muestra en la fotografía No. 1, el epitelio vaginal comprometido $y$ el contiguo a la lesión, mostró cambios significativos a lo largo del tratamiento.

Después de dos semanas de aplicación de 5-FU, la inflamación se hizo muy aparente y este período constituia el de mayor sintomatología durante el tratamiento (Fotografía No. 2).

Después de tres semanas sin interrupción el epitelio se desprendió y continuo haciendolo durante las dos semanas siguientes (Fotografía No. 3).

Tabla No 1

\begin{tabular}{|c|c|l|l|}
\hline Caso & Edad & Antes del tratamiento & Después del tratamiento \\
\hline I & 74 & Carcinoma In Situ & $\begin{array}{l}\text { Displasia Mínima } \\
\text { (Papanicoulou reportado } \\
\text { dentro límites normales) }\end{array}$ \\
\hline II & 45 & Carcinoma In Situ & Epitelio Normal \\
\hline III & 53 & Carcinoma In Situ & Epitelio Normal \\
\hline IV & 34 & Displasia Moderada & Epitelio Normal \\
\hline V & 19 & $\begin{array}{l}\text { Displasia severa } \\
\text { (muy sospechosa de } \\
\text { carcinoma In Situ) }\end{array}$ & Displasia Moderada \\
\hline VI & 39 & $\begin{array}{l}\text { Carcinoma In Situ } \\
\text { Epitelio Normal }\end{array}$ \\
\hline
\end{tabular}


Tabla No. 2

\begin{tabular}{|c|c|c|c|}
\hline Paciente & Tipo de Lesión & $\begin{array}{l}\text { Razón de la } \\
\text { Histerectomía }\end{array}$ & $\begin{array}{l}\text { Intervalo de tiempo desde el } \\
\text { primer diagnóstico de cáncer } \\
\text { genital hasta la apariencia } \\
\text { de neoplasia vaginal }\end{array}$ \\
\hline $\mathrm{SH}$ & Ca In Situ & Benigna & 26 años \\
\hline GB & Ca In Situ & $\begin{array}{l}\text { Ca In Situ } \\
\text { Cervix }\end{array}$ & 3 meses \\
\hline LP & $\begin{array}{l}\text { Ca In Situ } \\
\text { Displasia } \\
\text { Moderada }\end{array}$ & $\begin{array}{l}\text { Ca In Situ } \\
\text { Cervix }\end{array}$ & 9 años \\
\hline JK & $\begin{array}{l}\text { Displásia } \\
\text { Moderada }\end{array}$ & Ca In Situ & 5 años \\
\hline SM & $\begin{array}{l}\text { Dispalsia } \\
\text { Severa } \\
\text { Adenosis }\end{array}$ & No Histerectomía & \\
\hline BB & Ca In Situ & Ca In Situ & 4 meses \\
\hline
\end{tabular}

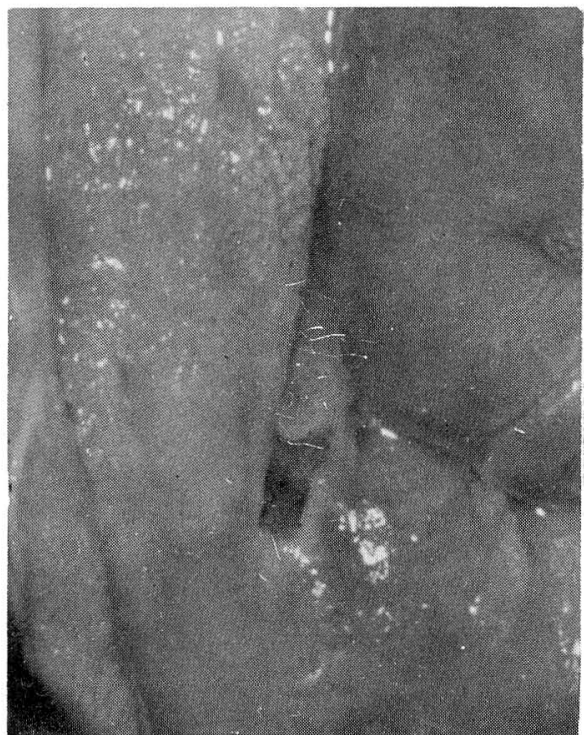

Foto No. 1

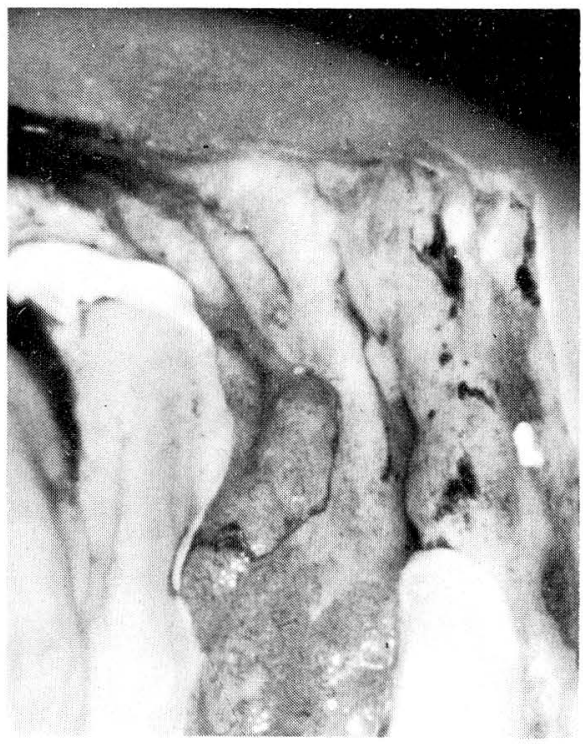

Foto No. 2 


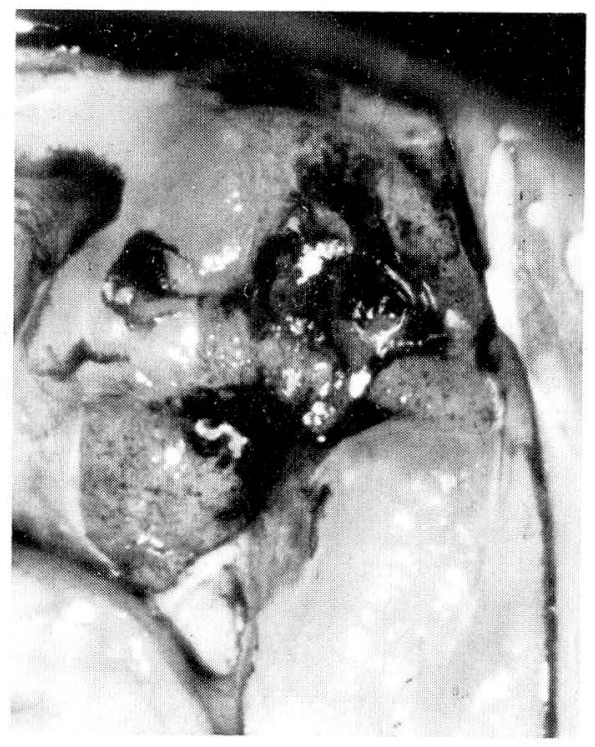

Foto No. 3

La formación de un nuevo epitelio es el hecho más sobresaliente durante la quinta semana (Fotografía No. 4).

\section{DISCUSION}

Una forr a diferente de tratamiento usando 5-FU en carcinoma in situ y en lesiones precancerosas en la vagina fue llevado a cabo en seis de nuestras pacientes. El promedio de edad y su historia ginecológica generalmente precedida por carcinoma en el tracto genital son similares a reportes encontrados por otros investigadores. El porcentaje de éxito alcanzado fue alto y muy de acuerdo con reportes anteriores.

Esta modalidad de tratamiento es barata y sus resultados son comparables a otros métodos más agresivos como lo son la cirugía y la radioterapia. El hecho de que 5-FU solamente actua en tejidos donde la actividad metabólica es acelera-

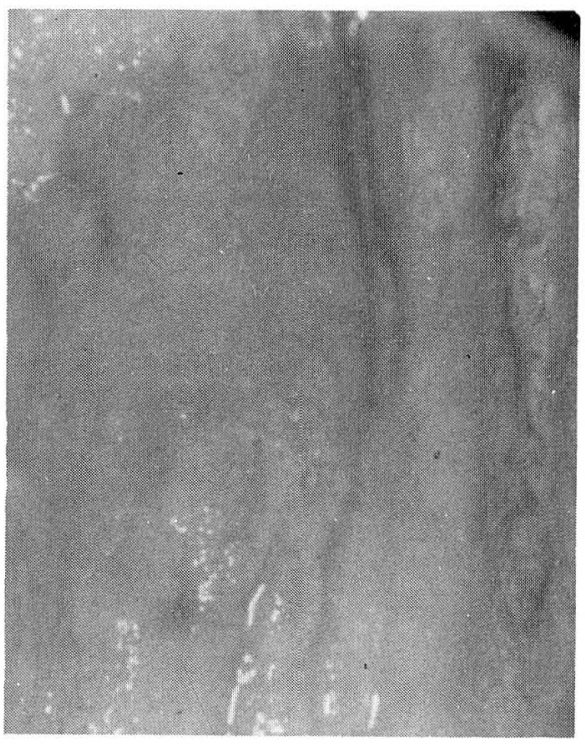

Foto No. 4

da hace de esta forma de tratamiento una de las de menos incomodidad para la paciente. Los tejidos normales solo presentaron mínima reacción. Al ser el sistema inmunológico en la paciente activado se le garantiza que zonas anormales que no han sido detectados van también a recibir el tratamiento. Una de las ventajas de mayor interés con esta forma de terapia es la preservación de la función en toda su extensión después de concluir el tratamiento.

La condición general del paciente no influyó en la selección de esta forma de terapia, pero no debemos olvidar que esta forma de quimioterapia debe ser considerada en casos donde otros procedimientos no son indicados.

El seguimiento de las pacientes al menos un año más tarde no mostró recurrencia y todas las citologías son reportadas dentro de límites normales. 


\section{CONCLUSION}

Una nueva modalidad de tratamiento de lesiones malignas y premalignas en seis casos se presenta como una nueva evi dencia de la alta probabilidad de éxito a través de una forma sencilla y poco sintomática de terapia que ofrece beneficios no obtenibles con otra forma de tratamiento.

La probabilidad de éxito utilizando esta forma de tratamiento es de $80 \%$ que es muy comparable con los resultados obtenidos en el tratamiento de carcinoma in situ de la vulva con 5-FU. Efec-

\section{REFERENCIAS}

1. SCOKEL, P.W., COLLIER, R.C., JONES W.N. et al: Relation of carcinoma in situ of the vagina to the early diagnosis of vaginal cancer. American Journal of Obstetrics and Gynecology 82: 397, 1961.

2. COPENHAVER, E.H., SALZMAN, F.A WRIGHT, K.A. Carcinoma in situ of the vagina. American Journal of Obstetrics and Gynecology 89: 962, 1964.

3. FERGUSON, J.H. MACLURE, J.G.: intraepithelial carcinoma, dysplasia, and exfoliation of cancer cells in the vaginal mucosa. American Journal of Obstetrics and Gynecology 87: 326, 1963.

4. HUMMER, W.K., MUSSEY, E., DECKER, D.G., et al: Carcinoma in situ of the vagina. American Journal of Obstetrics and Gynecology 108: 1109, 1970.

5. WOODRUFF, J.D., PARMLEY, T.H. JULIAN, C.G.: Topical 5-Fluorouracil in the treatment of vaginal carcinoma in situ. Gynecologic Oncology 3:125, 1975.

6. RUTLEDGE, F.: Cancer of the vagina. American Journal of Obstetrics and Gy. necology 97: 635, 1967. tos sistémicos tóxicos secundarios al tratamiento no se presentaron.

La neoplasia vaginal tiene un porcentaje de recurrencia del $25 \%$ independientemente del tratamiento utilizado. Nuestra serie de pacientes aunque no presenta esta evidencia es considerada de al to riesgo y citología además de biopsia cuando sea indicado, son procedimientos indispensables en su seguimiento a largo plazo. El uso de 5-FU en el tratamiento de lesiones que recurran también muestran resultados con alta probabilidad de éxito.

7. BALLON, S.C.: Colposcopy in the followup of women with lower genital tract or perianal carcinoma. Journal of the $\mathrm{Ca}$ nadian Medical Association 114: 340, 1976.

8. GALLUP, D.G., MORLEY, G.W.: Carcinoma in situ of the vagina. Obstetrics and Gynecology 122: 352, 1975.

9. USHERWOOD, M. McD.: Management of vaginal carcinoma after hysterectomy. American Journal of Obstetrics and Gynecology 122: 352, 1975.

10. BOWEN-SIMPKINS, P., HULL, M. G.R.: Intraepithelial vaginal neoplasia following immunosuppressive therapy treated with topical 5-FU. Obstetrics and Gynecology 46: 360. 1975.

11. HULL, M.G.R., BOWEN-SIMPKINS, P., PAINTIN, D.B.: 5-FU or DNCB for non-clinical vaginal and cervical cancer . Lancet 1: 1238, 1976

12. HULL, M.G.R., BOWEN-SIMPKINS, P., PAINTIN, D.B.: 5-FU versus immunotherapy for non-clinical vaginal cancer. Lancet 1: 588, 1976. 
13. HULL, M.G.R., BOWEN-SIMPKINS, P. PAINTIN, D.B.: Topical treatment of vaginal intraepithelial neoplasia. Obstetrics and Gynecology 49: 382, 1977.

14. KLEIN E., HELM, H., et al: Tumors of the skin, keratoacanthoma: Local effects of 5-Fluorouracil. Skin 1: 153, 1962.

15. LITWIN, M.S., RYAN, R.F., REED, R.J., et al: Topical chemotherapy of advanced cutaneous malignancy with 5Fluorouracil creme. Journal of Surgical Oncology 3: 351-365, 1971.

16. LITWIN, M.S., KREMENTZ, E.T., MAN SELL, P.W., et al: Topical chemotherapy of lentigo maligna with 5-Fluorouracil creme. Cancer 35: 721-733, 1975.

17. LITWIN, M.S., KREMENTZ, E.T.: Treatment of basal and squamous cancers of the nose and ear with 5-Fluorouracil creme. Laryngoscope 81: 840-847, 1971.

18. MANSELL, P.W., LITWIN, M.S., ICHI-

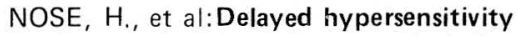
to 5-Fluorouracil following topical chemotherapy of cutaneous cancers. Cancer Research 35: 360-367, 1976.

19. KRUPP, P.J., BOHM, J.W., LEE, F. Y. L., et al: Epidermoid cancer of the vulva, Cancer :6: 360-367, 1976
20. WOODRUF, J.D., JULIAN, C., PURAY, $T$., et al: The contemporary Challenge of carcinoma in situ of the vulva. American Journal of Obstetrics and Gynecology, 115, 677-686, 1973.

21. CARSON, T.E., HOSKINS, W.J., WURZEL, J.F.: Topical 5-Fluorouracil in the treatment of carcinoma in situ of the vulva. Obstetrics and Gynecology 47 (Supplementary): 59-66, 1976.

22. DEAN, R.E., TAYLOR, E.S., WEIS. BROD, D.M., et al: The treatment of premalignant lesions of the vulva. American Journal of Obstetrics and Gynecology 119: 59-68, 1974.

23. HUGHES, R.R.: Early diagnosis and management of premalignant lesions and early invasive cancers of the vulva. Southern Medical Journal 64: 1490-1492, 1971.

24. LIMMER, B.L.: Bowen's Disease: Treatment with topical 5-Fluorouracil. Cutis 16: 660-663, 1975.

25. JANSEN, G.T. DILLAHA, C.J., HONEY. CUTT, W.M.: Bowenoid conditions of the skin: Treatment with topical 5Fluorouracil. Southern Medical Journal 60: 185-188, 1967. 